\title{
Identification of Filarial Parasites in Animals in Human Lymphatic Filariasis Endemic Areas in Central Kalimantan, Indonesia
}

\author{
Nita Rahayu ${ }^{1}$, Yuniarti Suryatinah ${ }^{1}$, Mara Ipa $^{2, *}$, Triwibowo Ambar Garjito ${ }^{3}$, Pandji \\ Wibawa Dhewantara ${ }^{2}$
}

\begin{abstract}
${ }^{I}$ Tanah Bumbu unit for Health Research and Development National Institute of Health Research and Development, Ministry of Health, Indonesia

${ }^{2}$ Pangandaran unit for Health Research and Development National Institute of Health Research and Development, Ministry of Health, Indonesia

${ }^{3}$ Institute for vector and reservoir control research and development, National Institute of Health Research and Development, Ministry of Health, Indonesia
\end{abstract}

*Corresponding Author. Email: tiarmara@gmail.com

\begin{abstract}
The re-emergence of Brugian filariasis after mass drug administration (MDA) has been documented in Indonesia. A third-round of transmission assessment survey (TAS) in Kotawaringin Barat district revealed positive anti-Brugia IgG4 antibodies in humans, indicating a newly emerged Brugian filariasis transmission. Yet, recent microfilaria (Mf) status in animals is unclear. This study aimed to assess ongoing Brugia transmission in reservoir which could be potential reservoirs of lymphatic filariasis Cross-sectional surveys were carried out in Sungai Bakau and Dawak village in Kotawaringin Barat, Central Kalimantan to examine blood samples for microfilaria (Mf). Night blood smears (NBS) were collected animal reservoirs include cats (Felis catus), dogs (Canis familiaris) and long-tailed macaque (Macaca fascicularis) and were assessed by microscopic examination and conventional polymerase chain reaction (PCR). Overall, total of 101 blood samples of reservoirs were screened. Microfilaria of Brugia malayi was identified in cats (Felis catus) $(\mathrm{n}=6 / 79)$, long-tailed macaque (Macaca fascicularis) $(\mathrm{n}=1 / 5)$, and dogs (Canis familiaris) $(\mathrm{n}=1 / 1)$. This study indicates the possible interplay between animals and humans in maintaining the LF transmission in Kotawaringing Barat, Kalimantan. Brugia spp. identified as the source of LF infection in these areas. This study recommends the needs to strengthen LF surveillance to reduce LF transmission so that the goal of elimination can be achieved. A One-Health partnership is necessary to control transmission in LF endemic areas.
\end{abstract}

Keywords: lymphatic filariasis, Brugia spp., reservoir, Central Kalimantan

\section{INTRODUCTION}

Globally, it is estimated that 120 million people are infected by lymphatic filariasis (LF) and 40 million suffer from chronic disabilities [1]. In 2000, the World Health Organization launched Global Program to Eliminate Lymphatic Filariasis (GPELF) aiming to eliminate LF as public health problem in 2020. This program comprises two strategies: first, a once-annually mass drug administration (MDA) of single doses of diethylcarbamazine and albendazole for at least 5 years, and secondly, a morbidity management and disability prevention by providing access to health care facility to every clinically infected people in endemic areas [2,3].

The LF epidemiology is unique in Indonesia because it is caused by three different filarial species, including Wucheria bancrofti, Brugia malayi, and B. Timor and each have distinct vector species and ecological ecotypes. This heterogeneity leads to different patterns of transmission and therefore different strategies of intervention are required [4]. Until 2015, LF were endemic in 239 out of 514 districts across Indonesia. Yet, only 132 districts had implemented MDA-LF. For some reasons, 58 endemic districts had not implemented MDA. There were 48 districts have completed the MDA-LF for 5 consecutive years, but only 26 districts had passed post-MDA survey (Transmission Assessment Survey /TAS) and 22 districts failed the evaluation phase, thus they must implement additional MDA for two consecutive years for further evaluation [5].

In South-East Asia, particularly Indonesia and Malaysia, a wide variety of non-human primates (gibbons, macaques, leaf monkeys and orangutans) are present. The macaques (Macaca spp.) and the leaf monkeys (Presbytis spp.) are the most common among these. Some representatives of these genera in Indonesia and Malaysia are important reservoirs 
of zoonotic filariasis. Recent studies show that they play an important role in endemic areas in the epidemiology of human filariasis. The contibution to the zoonotic pool of carnivores, domestic cats and other species is still unknown [6]. Study in India revealed D. repensis identified as the most common species of filarial worm and another important finding of the study was the presence of Brugia species in the dogs which the most prevalent Brugia species identified was $B$. pahangi [7]. This was shown by study in Malaysia in subperiodic B. Malayi endemic areas accompanied by a corresponding increase in the rate of microfilarial prevalence in humans. The cats were probably

\section{METHOD}

Study Area. A cross-sectional survey was carried out in Sungai Bakau and Dawak village in West Kotawaringin, Central Kalimantan in 2017 (Figure 1). Study sites were selected based on the occurrence of brugian filariasis cases based on the third round of TAS in 2016. Finding of TAS3 in West Kotawaringin district have shown that there were four cases of positive anti-Brugia IgG4 antibodies for $B$. malayi in these two villages [8].

We performed environmental survey aiming at characterizing biotic and abiotic environmental conditions and potential breeding sites aroud the study sites. Sungai Bakau village is situated in coastal area and surrounded by secondary forest. Wild primates are rarely found. While Dwak village situated primary forest $(5 \mathrm{~km}$ before enter the village). Surrounded by secondary forest and commercial plantation (rubber and palm). Wild primates are rarely found.

\section{Data collection}

Reservoir blood samples. In both sites, potential reservoirs include cats (Felis catus), dogs (Canis familiaris) and longtailed macaques (Macaca fascicularis) were purposively sampled. For each species, a minimum number of samples of 100 individuals was set. Cats and domestic dogs aged minimum 6-months old were screened. Blood collection were conducted at night, sedated using ketamine hydrochloride. Prior to blood sampling, consent was sought from the owner. From each animal, a blood sample of minimum $1 \mathrm{cc}$ was taken from the vein savena (cat / dog) or femoral vein (long-tailed macaque). Thick blood smears

\section{RESULTS AND DISCUSSION}

A total of 101 of blood samples of reservoirs were screened, 17 dogs (domestic), 79 cats (domestic) and 5 long-tailed macaques (stray) from both study sites. Was identified in cats $(n=3), \operatorname{dog}(n=1)$ and long-tailed macaque $(n=1)$. In Sungai Bakau village, we identified in cats $(n=1 / 48)$ and long-tailed macaque $(\mathrm{n}=1 / 3)$. In Dawak village, $B$. malay infected from man and their infection rate is a reflection of the endemicity area [6].

Based on a third-round of transmission assessment survey (TAS) in Kotawaringin Barat district revealed positive antiBrugia IgG4 antibodies in humans, indicating a possible emergence of Brugian filariasis transmission. Yet, recent microfilaria (Mf) status in humans and animals is unclear. This finding must be taken very seriously since it could therefore, this study was aimed to assess ongoing Brugia transmission in reservoir which could be potential reservoirs of lymphatic filariasis.

(TBS) $(60 \mu \mathrm{l})$ was prepared and stained with Giemsa. The microfilariae were identified under microscope. The remaining blood was spotted on to filter paper for further molecular analysis.

DNA extraction and PCR analysis. DNA was extracted from animal reservoir blood samples using a DNeasy® Blood \& Tissue Kit (Qiagen, Hilden, Germany) with modification based on the manufacturer's protocol. The amplification of Express Sequence Tags (EST), highly repeated sequence of filarial DNA and homologous sequence in the genome of Brugia malayi was performed with primers Hha1 F (5'-GCG CAT AAA TTC ATC AGC3') and Hha1R (5'-GCG CAA AAC TTA ATT ACA AAA GC-3')[9,10]. PCR reactions were carried out using GoTaq ${ }^{\circledR}$ Green Master Mix (Promega, Madison, WI, USA). PCR thermocycling conditions were as follows: 94 ${ }^{\circ} \mathrm{C}$ for $5 \mathrm{~min}$; followed by 35 cycles of denaturation at 94 ${ }^{\circ} \mathrm{C}$ for $1 \mathrm{~min}$, annealing at $59.6{ }^{\circ} \mathrm{C}$ for $1 \mathrm{~min}$ and elongation at $72{ }^{\circ} \mathrm{C}$ for $1 \mathrm{~min}$; followed by a final extention step at 72 ${ }^{\circ} \mathrm{C}$ for $10 \mathrm{~min}$. The amplified PCR products were separated by $1.5 \%$ agarose gel electrophoresis and vizualized by SYBR ${ }^{\circledR}$ safe DNA gel stain (Invitrogen, Carlsbad, CA, USA). A 100-bp DNA ladder was used for calculating the size of the PCR products. Amplification products were purified using Applied Biosystems ExoSAP-ITTM (Thermo Fisher Scientific, Vilnius, Lithuania). Samples were confirmed as positive for $B$. Malayi based on the amplified DNA fragment size of 322 bp [9,10].

Data analysis. Data were recorded in Microsoft Excel. Descriptive analyses were conducted using SPSS ver.22 (IBM Corp, Armonk, NY, USA) for analysis

was positively identified in cats $(n=2 / 31)$ and dogs $(n=1 / 17)$ (Table 1). In addition, we identified other three species of filarial parasites from blood samples, including B. pahangi, Dirofilaria immitis and D. repens., it was different with $B$. malayi was identified by conventional polymerase chain reaction analysis. 
Table 1. Animal reservoirs of microfilariae identified in study sites during the survey based on microscopic examination and conventional polymerase chain reaction.

\begin{tabular}{|c|c|c|c|c|c|c|c|}
\hline \multirow[b]{2}{*}{ Site } & \multirow[b]{2}{*}{ Species } & \multirow[b]{2}{*}{$\mathrm{N}$} & \multicolumn{5}{|c|}{$\mathrm{n}(\%)$} \\
\hline & & & $\begin{array}{c}+ \text { ive } \\
\text { B.malayi }\end{array}$ & $\begin{array}{l}+ \text { ive } B . \\
\text { pahangi }\end{array}$ & $\begin{array}{c}+ \text { ive } \\
\text { Dirofilaria } \\
\text { immitis }\end{array}$ & $\begin{array}{l}+ \text { ive } \\
\text { Dirofilaria } \\
\text { repens }\end{array}$ & $\begin{array}{c}+ \text { ive } \\
\text { (B.malayi }+ \\
\text { Dirofilaria } \\
\text { repens) }\end{array}$ \\
\hline \multirow[t]{3}{*}{$\begin{array}{l}\text { Sungai } \\
\text { Bakau }\end{array}$} & $\begin{array}{l}\text { Cats } \\
\text { (Felis catus) }\end{array}$ & 48 & $1(2.08)$ & $0(0.00)$ & $1(2.08)$ & $16(33.33)$ & $3(6.25)$ \\
\hline & $\begin{array}{l}\text { Dogs } \\
\text { (Canis familiaris) }\end{array}$ & 0 & $0(0.00)$ & $0(0.00)$ & $0(0.00)$ & $0(0.00)$ & $0(0.00)$ \\
\hline & $\begin{array}{l}\text { Long-tailed macaque } \\
\text { (Macaca fascicularis) }\end{array}$ & 3 & $1(33.33)$ & $0(0.00)$ & $0(0.00)$ & $0(0.00)$ & $0(0.00)$ \\
\hline \multirow[t]{4}{*}{ Dawak } & $\begin{array}{l}\text { Cats } \\
\text { (Felis catus) }\end{array}$ & 31 & $2(6.45)$ & $0(0.00)$ & $0(0.00)$ & $0(0.00)$ & $0(0.00)$ \\
\hline & $\begin{array}{l}\text { Dogs } \\
\text { (Canis familiaris) }\end{array}$ & 17 & $1(5.88)$ & $0(0.00)$ & $4(23.52)$ & $0(0.00)$ & $0(0.00)$ \\
\hline & $\begin{array}{l}\text { Long-tailed macaque } \\
\text { (Macaca fascicularis) }\end{array}$ & 2 & $0(0.20)$ & $0(0.00)$ & $0(0.00)$ & $0(0.00)$ & $0(0.00)$ \\
\hline & Total & 101 & $5(4.95)$ & $0(0.00)$ & $5(4.95)$ & $16(15.84)$ & $3(2.97)$ \\
\hline
\end{tabular}

West Kotawaringin was endemic for brugian filariasis and after passed the third round of MDA revealed positive antiBrugia IgG4 antibodies in humans. These findings indicating a newly emerged of Brugian filariasis transmission, yet recent microfilaria (Mf) status in animals is unclear. The primary objective of this survey was to assess ongoing Brugia transmission in reservoir which could be potential reservoirs of lymphatic filariasis. Our study revealed potential $B$. malayi reservoirs in West Kotawaringin district including cats, dogs and long-tailed macaques. Of which, cats were the most dominant $B$. malayi reservoir in the area. Filarial parasites among cats have been mostly studied in Southeast Asia where cats were implicated as reservoir hosts for human lymphatic filariasis [11,12]. Among filarial species, Dirofilaria repens was found to be the most dominant species found in the animals. Our finding is consistent with that studies in Srilanka and India[7] that also reported high prevalence of D. repens in animals [13].

The filarial worm is transmitted by various mosquito species belong to genus of Anopheles, Aedes, Culex, Mansonia, and Ochlerotatus. Of which, Mansonia bonneae, which belong to the genus Mansonia, is the main vector of Brugia malayi which responsible for brugian filariasis cases in Dayak Krayan [14]. The habitat of Ma. bonneae in the area is mostly found in the environment in dense forests and the main predominant species from other Mansonians. This type of ecosystem is typical with that observed in Dawak Village which is also a forest area and also commonly found in Ma. Bonneae [15], while in Sungai Bakau Village is a coastal area also found by Ma. Bonneae [16]. The physical environment was related to the existing of the vector, which can influence the emergence of infectious sources of infection. The physical environment can create mosquito breeding places. Temperature and humidity affect the growth, life and presence of mosquitoes [17-19]. The environment with aquatic plants in swamps and the presence of reservoir (monkeys, long-tailed macaque, and cats) influences the distribution B. malayi sub-periodic and non-periodic biodiversity [3]. Both Sungai Bakau and Dawak Villages environmental situated is in coastal area and surrounded by secondary forest and there were found many potential vector breeding places.

Filarial parasite was identified both microscopic examination and conventional PCR assay. Although microscopic examination of microfilariae known as gold standard and the most widely accepted diagnostic tools for filarial worm infections, however it has limitations in terms of sensitivity during large scale screening, particularly in low or very low endemic areas. This method requires great effort for both the patients as well as the collector, because the blood samples collection must be done at night between 20:00 to 2.am. For this reason, we use the molecular method as part of this study. DNA based detection method has been reported to have better sensitivity and specificity than conventional methods. Moreover,this method can be applied with more flexible time for blood collection, both day and night $[20,21]$.

Based on the results of multicenter research in West Kotawaringin in 2017 showed 5 people were identified containing microfilaria B. malayi in their blood [15]. The presence of filarial worms in animals in this areas may pose a major threat for the elimination of LF in West Kotawaringin. The findings indicate that LF transmission in humans is likely to exist in these areas as these animals live in the proximity of human settlements, suggesting the needs to improve vector control and surveillance. However, the potential of these animals acting as reservoirs of human brugian filariasis need to be further investigated. It is also evident that establishment of veterinary control programs at this point is essential in order to reduce human exposure to infection. From a public health perspective, while the 
[11] Al-Abd NM,Nor ZM,Kassim M,MansorM,AlAdhroey AH,NguiR et al. Prevalence of filarial parasites in domestic and stray cats in Selangor State,Malaysia. Asian Pac J TropMed [Internet]. 2015;Sep;8(9):705-709. Available from: https://doi.org/10.1016/j.apjtm.2015.07.034PMI D:26433654 prese microfilaria in domestic animals warrant animals (e.g., cats and dogs) to prevent LF transmission.

\section{CONCLUSION}

Our study indicates the possible interplay between animals and humans in maintaining the LF transmission in Kotawaringing Barat, Kalimantan. Brugia spp. identified as the source of LF infection in these areas.This study recommends the needs to strengthen LF surveillance to reduce $\mathrm{LF}$ transmission so that the goal of elimination can be achieved. A One-Health partnership is necessary to control transmission in LF endemic areas.

\section{REFERENCES}

[1] World Health Organization. Lymphatic filariasis: Key facts. WHO Media Cent [Internet]. 2015;(May):1. Available from: http://www.who.int/mediacentre/factsheets/fs102 len/

[2] WHO. Resolution WHA 50.29: Elimination of lymphatic filariasis as a public health problem. Fiftieth World Heal Assem. 1997;(3):27-8.

[3] Kementerian Kesehatan RI. Permenkes RI No 94 Tahun 2014 tentang Penanggulangan Filariasis. Jakarta: Kementerian Kesehatan RI; 2015.

[4] Fischer P,Supali T M. Lymphatic filariasis and Brugia timori: prospects for elimination. Trends Parasitol. 2004;20:: 351-355.

[5] Kementerian Kesehatan RI. Situasi Fialriasis Indonesia Tahun 2015. 2016; Available from: http://www.pusdatin.kemkes.go.id/resources/dow nload/pusdatin/infodatin/Infodatin-Filariasis2016

[6] WHO. Lymphatic Filariasis Fourth Report of The WHO Expert Committee on Filariasis. Genveva; 1984. p. 1-114.

[7] Ravindran R, Varghese S, Nair SN, Balan VM, Lakshmanan B, Ashruf RM, et al. Canine Filarial Infections in a Human Brugia malayi Endemic Area of India. 2014;2014.

[8] Dinas Kesehatan Kabupaten Kotawaringin Barat. Laporan Hasil Transmission Assessment Survey (TAS)-2 Kabupaten Kotawaringin Barat Provinsi Kalimantan Tengah. 2016.

[9] B2P2VRP. Pedoman Pengelolaan dan pemeriksaan spesimen di laboratorium Riset Khusus Vektora 2017. B2P2VRP, Badan Litbang Kesehatan.; 2017.

[10] Saeed M, Siddiqui S, Bajpai P, K.Srivastava A MH. Amplification of Brugia malayi DNA using Hha1 Primer as a Tool. Open Conf Proc Journal. 2014;5:38-40.
[12] Muslim A,Fong MY,Mahmud R S. Vector and reservoir host of a case of human Brugia pahangi infection in Selangor,peninsular Malaysia. TropBiomed [Internet]. 30(4):727-730. Available from: pmid:24522144

[13] Id CHM, Id NTGAC. A preliminary survey of filarial parasites in dogs and cats in Sri Lanka. 2018;1-11.

[14] F S. Mansonia bonneae (diptera: culicidae) sebagai vektor utama filariasis yang disebabkan oleh Brugia malayi nonperiodik di daerah penduduk asli Dayak di Kalimantan Timur. Berk Ilmu Kedokt [Internet]. XXXI(4):14-21.

[15] Nita Rahayu et.al. STUDI EVALUASI Eliminasi Filariasis Di Indonesia Tahun 2017: Kabupaten Kotawaringin Barat Dan Kabupaten Hulu Sungai Utara (Daerah Endemis Brugia malayi Zoonotik). Tanah Bumbu; 2017.

[16] Badan Litbang Kesehatan Kementrian Kesehatan Republik Indonesia. Studi Evaluasi Eliminasi Filariasis di Indonesia tahun 2017 (Studi Multisenter Filariasis). 2017.

[17] Denlinger, D.L.; Yocum GD. Physiology of heat sensitivity. InTemperature Sensitivity in Insects and Applicationin Integrated Pest Management. Oxford, UK, 1998; pp. 7-53. ; Hallman, G.J., Denlinger, D.L., Eds.; Westview Press: Boulder, CO, USA;Oxford, UK, 1998; pp. 7-53: Westview Press: Boulder, CO, USA; 1998. 7-53 p.

[18] Tunggul Satoto TB, R Umniyati S, Suardipa A, M Sintorini M. Effects of Temperature, Relative Humidity, and DEN-2 Virus Transovarial Infection on Viability of Aedes aegypti. Kesmas. 2013;

[19] Epstein PR. Climate change and emerging infectious diseases. Microbes Infect. 2001 Jul;3(9):747-54.

[20] Rao RU, Weil GJ, Fischer K, Supali T, Fischer P, Icrobiol JCLINM. Detection of Brugia Parasite DNA in Human Blood by Real-Time PCR $\square$. 2006;44(11):3887-93.

[21] Fischer, P., T. Supali, H. Wibowo, I. Bonow and SAW. Detection of DNA of nocturnally periodic Brugia malayi in night and dayblood samples by a polymerase chain reaction-ELISA-based method usingan internal control DNA. Am J Trop Med Hyg. 2000;62:::291-296. 